\title{
Preliminary Note on the Algae of Crystal Cave, Kentucky
}

\author{
By J. P. NAGY ${ }^{1}$ )
}

With 3 figures in the Text

\section{Introduction}

In connection with the International Zoological Congress held in Washington, D.C. in 1963 we had an opportunity to pay a visit to the Kentucky Karst Region and to investigate the Mammoth and Crystal Caves. On this occasion we collected some material from Crystal Cave which seemed to contain algae and the results of this preliminary study are presented here. One must point out in advance that our collections did not follow any systematic pattern; altogether only four samples were taken, which served only to ascertain whether or not algae occur at all in Crystal Cave and if so, to supply a basis for more thorough investigations.

Since the works of Claus (1955, 1960, 1962 a, 1962 b, 1964a, 1964b); Friedmann (1955, 1956, 1961, 1962); Palik (1960a, 1960b) and Suba (1957) the attention of botanists has become focused on an almost forgotten area of research, phyto-speleology. Around the turn of the XIXth century this new branch of science underwent a startling beginning and rapid development, especially in Western Europe, just to submerge again into oblivion. The cause for this may well lie in more than one factor. Earlier workers, being unaware of the possibility that chlorophyll containing green pigmented plants may utilize organic matter for their assimilatory activity without or in the presence of only minimal illumination, thought that the plants they found in the caves had to make use of the amount of light, no matter how small it was, for conducting their life processes. In such instances when penetration of light in the depth of caves could be satisfactorily excluded the presence of only truly heterotrophic species was expected and, indeed, besides fungi or bacteria no plant has been reported from the interior of caves by the majority of workers. In the few cases

1) Biological Institute, Matthew Maury Research Center, Long Island, N.Y. Present Address : 27 Parkwood Ave. Toronto 7, Ontario, Canada. 
when algae, mosses, etc. were found to grow in the total darkness of the deep cave environment the investigators were forced to come up with fantastic explanations for the seemingly autotrophic thriving of plants in the darkness. Just to mention an example, Maheu (1903), the otherwise excellent biospeleologist, in order to solve the question of assimilation came to the conclusion that the green pigmented plants utilize the light emitted by fluorescent fungi. Naturally such hypotheses were accepted with grave scepticism on the part of the scientific community and other investigators quickly came to the conclusion that either the reports of the presence of pigmented plants in the caves were erroneous or if they really occurred, they must have been accidental elements swept in recently, or could be found only in the form of spores or other "surviving organs," or that they lived in the photic zone. If any of the above enumerated explanations are seriously taken, however, there is but little space left for a botanist to work in a cave. The true heterotrophs, for instance fungi growing on old $\log _{\mathrm{s}}$, or plants occurring in the photic zones of the caves did not yield versatile enough material for investigations, and on the other hand no interest was aroused in investigating the "accidentally swept in forms" or determining what kind of "spores or other reproductive units" may have been carried into the caves. In view of the above considerations it is not surprising that after the ebbing of the initial enthusiasm near the end of World War I, only a scattered literature now deals with phyto-speleology. Thus, the papers of Claus (loc. citt.), etc. actually fell into a more or less complete vacuum and by trying to revitalize a once thriving, but by then almost dead, branch of science they were greeted again with scepticism.

As it was pointed out earlier we entered this field of investigation with exactly the same kind of scepticism in our minds and more out of curiosity than due to scientific conviction we collected a few samples from areas presumably habitated by algae. The results of the direct microscopic investigations and of the culturing experiments were rather surprising which warrants their publication.

Crystal Cave is part of the Flint Ridge Cave System and is located in the Central Kentucky Karst. In spite of its extensive interconnecting passages it was not discovered and opened to exploration until 1917. Unfortunately, its discoverer, Floyd Collins, did not conduct any intensive investigations and until 1947 when Dyer and his group started to map the cave, no detailed studies concerning this major cave of the Flint Ridge System had been done (see in Smith, 1964). The idea that the five major caves occurring in the Flint Ridge region are interconnected with each other was already supposed by 
the French speleogist, Le Couppey De La Forrest (1903). His paper, however, did not give rise to sufficient interest among cave researchers in trying to prove or disprove his theory. Only lately (August, 1961) a group headed by Keller, Deamer, Werner, and Powell (see in Smith, 1964) was able to demonstrate that there is a single connected cave system below the Flint Ridge, composed of Crystal, Unknown, Colassal, and Salts Caves. By now a total of 35 miles of passages have been surveyed and it seems that some of the as yet unmapped passages may connect the Flint Ridge System to the world's largest cave to the south, the Mammoth Cave.

The Kentucky Karst is built up from oölitic Ste. Geneviève and Girken limestones of Chester and Merramac Ages and in these limestones the cave passages are excavated. The limestones are covered with a thick (at places $110 \mathrm{ft}$.) layer of Cypress Sandstone. The layers of these formations incline towards the Green River (to the northwest), which collects most of the underground waters of the caves.

According to Watson and Smith (1963) the relative humidity in the caves of this system varies between 80 to 100 per cent, and similarly the temperature and air flow show considerable fluctuations. These microclimatic conditions exhibiting such variance in a single cave may result in a great variety of microhabitats with different faunas and floras.

The installation of electrical illumination in Crystal Cave naturally may have produced some changes in the troglobitic fauna and flora of these underground habitats, but due to its rather recent electrification and the relatively smaller number of people than those visiting nearby Mammoth Cave, these changes cannot be too profound, especially in view of the fact that the lights are only turned on for short periods of time. Otherwise, except for the immediate entrance area, there is complete darkness in the entire cave.

\section{Materials and Methods}

For collecting material in the cave the methods recommended by Claus $(1955,1962 \mathrm{a}, 1962 \mathrm{~b})$ were used: with the aid of carefully sterilized instruments scrapings of the walls, stalactites or stalagmites were secured and placed into autoclaved collecting vials. By this technique it was hoped that any cross-contamination betwen the samples, or contamination by extraneous material could be avoided. This indeed seemed to be the case as the following cul- 
turing experiments resulted in two instances of monoalgal cultures.

Upon our return to the laboratories we immediately microscopically examined small quantities of the samples in order to ascertain the presence of actively vegetating algae. As it was pointed out by Claus (loc. citt.) such a procedure is impractical and rather tedious since large surface areas of the cave often harbor only one or a few algal cells. From this point of view we were in a rather fortunate situation as all of our samples contained some algae which became immediately apparent during the investigation of the native material. Sample Nos. 1 and 2 actually contained quite extensive thalli of a Chloro-, and a Rhodophyton which could be readily identified prior to culturing. One must add here that the Rhodophyton which turned out to be an Asterocytis species did not grow at all in the subsequent culturings. Thus, had only the cultured materials been investigated, it would never have been found. No spores or algae in resting stages could be found during these determinations.

After investigating the "native" samples the rest of the material was transferred under sterile conditions to autoclaved glass boxes, filled with sterile Knopp's solution and the boxes were placed in a culture chamber where they received an illumination of 18 hours per day, with approximately 2000 lux intensity. After about six weeks, when the material in the boxes showed signs of colorization, preparations were made from their contents and the algae found were identified. The rest of the material was further cultured for another six weeks, at the end of which time the boxes were reexamined. No form was found at this time, which had not been already observed at the previous determinations; only the quantities of the different species changed.

The localities from which the four samples collected in the cave originated and their macroscopic habit is the following:

Sample No. 1. Heavy, grass green growth around a lamp on a relatively dry wall surface close to the ceiling. About $400 \mathrm{~m}$. from entrance.

Sample No. 2. Extensive dark gray mucous growth in crevices of wall, wetted constantly by seeping water. About $450 \mathrm{~m}$. from entrance.

Sample No. 3. Whitish, fungal (?) growth on speleo-clay and lower portion of wall. About $480 \mathrm{~m}$. from entrance.

Sample No.4. Orange colored fungal (?) growth on small stalactites or stalagmites. About $550 \mathrm{~m}$. from entrance. 
Fig. 1. Portion of Crystal Cave. After Cave Research Foundation Map, 1963. Numbers indicate the localities of samples.

The approximate localities of the samples in the cave are marked on the included sketch.

For the identification a Leitz Ortholux research microscope with $40 \times, 63 \times$ and $93 \times$ objectives and with $12.5 \times$ oculars was used. The drawings were prepared with the aid of a camera lucida.

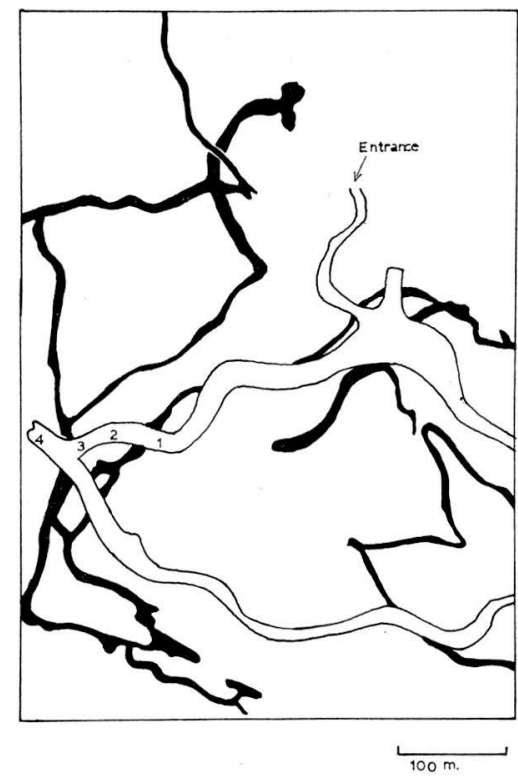

\section{TAXONOMY}

\section{CYANOPHYTA}

\section{Chamaesiphonaceae}

\section{CHAMAESIPHON GRACILIS Rabh.}

The specimens were found attached to the mineral substrate among the mucus of a red alga and were growing well under the artificial conditions, covering the small grains of limestones on the bottom of the culturing flasks. This finding seems to be the first report of a Dermocapsales from a cave. With the finding of CH. GRACILIS in Crystal Cave representatives of all of the orders of the Cyanophyta, except for the highly specialized Cyanophanales, have been described from a speleo-environment. Observed both without and with culturing. Fig. 1. Sample No. 2.

\section{Oscillatoriaceae}

\section{OSCILLATORIA NEGLECTA Lemm.}

This species seems to be a cosmopolitan, widespread form and has also been found in Mammoth cave (Jones, 1964). Observed both without and with culturing. Samples Nos. 2, 4. 


\section{BACILLARIOPHY'TA}

\section{Naviculaceae}

3. NAVICULA MUTICA Kütz. var. NIVALIS Kütz.

The variety has been reported from mountainous regions and usually a psychrophilic character is ascribed to it. Claus (1955) found it in the Baradla Cave at Aggtelek, Hungary, and evaluated its presence as a possible clue to the preglacial or glacial origin of the cave's algal flora; cf. "Discussion." Observed only in the cultured material, rather scarcely. Sample No. 4.

\section{PYRRHOPHYTA}

\section{Gymnodiniaceae}

\section{GYMNODINIUM TENUISSIMUM Laut.}

The finding of this motile form in a wall scraping of the cave is surprising. This seems to be the second report of the occurrence of a Pyrrhophyton in a cave; a swarmer - unfortunately not the adult form, thus we do not know the exact name of the species, of a Goniaulax has been described by Claus (1962a) from the underground river of the cave of Abaliget, Hungary. Seen only in the cultured material, among fungus hyphae. Sample No. 3 .

\section{CHLOROPHYTA}

\section{Palmellaceae}

\section{NEOCHLORIS MINUTA Arce et Bold}

The material of the sample was practically a pure culture of this species (a few bacteria were found among the algae). Observed both without and with culturing. Sample No. 1.

\section{Oocystaceae}

\section{SCENEDESMUS BRASILIENSIS Bohlin}

This originally planktonic, \pm eutrophic species occurred in quantities in sample No. 2, and was found easily without and with culturing. 


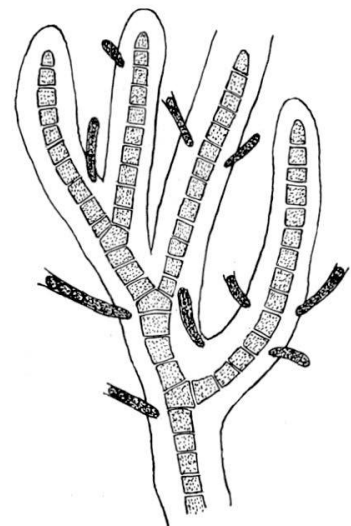

Fig. 2

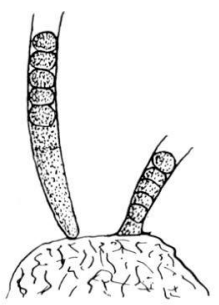

Fig. 2 a

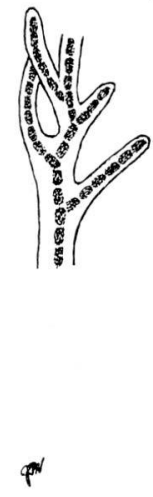

Fig. 3

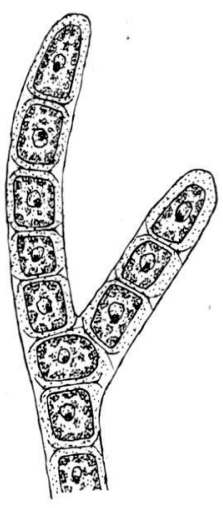

Fig. $3 \mathrm{a}$

Fig. 2. Chamaesiphon gracilis Rabh. Growing in the mucous matrix of Asterocytis smaragdiana. $550 \times$. a) Same as above but single individual attached to mineral debris. $1500 \times$.

Fig. 3. Asterocytis smaragdiana (Reinsch) Forti. General habit of colony. $100 \times$. a) Same as above, single filament. $750 \times$.

\section{RHODOPHYTA}

\section{Goniotrichaceae}

\section{ASTEROCYTIS SMARAGDIANA (Reinsch) Forti}

The highly mucous thalli of this species built extensive layers in the crevices of the limestone wall of the cave. The three other species found in this sample apparently used the mucus of the red alga either for nutrition or as a shelter. While A.smaragdiana did not grow in the cultures and could be studied only in the fresh preparations, the cohabiting species did well in the inoculum which may serve as an indication of their auxo-, if not autotrophic nature, i.e. they more probably just lived together with the Rhodophyton without using its mucous for nutrition.

To our knowledge a Bangioid red alga has as yet not been reported from the depths of a cave (cf. Friedmann, 1956, 1962; Geitler, 1943), thus by the finding of $A$.smaragdiana deep in Crystal Cave, representatives of both classes of the Rhodophyta in a true speleo-environment could be ascertained. Fig. 2. Sample No. 1.

Sample Nos. 3 and 4 contained also possibly more than one fungal species besides the algae; no attempt was, however, made either to culture or to identify them. 
Table 1

Occurrences of algae in the different samples

\begin{tabular}{l|c|c|c|c}
\hline Name of Species $\quad$ Sample No. & 1 & 2 & 3 & 4 \\
\hline $\begin{array}{l}\text { Asterocytis smaragdiana (Reinsch) Forti } \\
\text { Chamaesiphon gracilis Rabh. }\end{array}$ & & $\times$ & & \\
Gymnodinium tenuissimum Laut. & & $\times$ & & \\
Nasicula mutica Kütz. var. nisalis Kütz. & & & $\times$ & \\
Neochloris minuta Arce et Bold & $\times$ & & & $\times$ \\
Oscillatoria neglecta Lemm. & & $\times$ & & $\times$ \\
Scenedesmus brasiliensis Bohlin & $\times$ & & \\
\hline Total taxa: 7. & 1 & 4 & 1 & 2
\end{tabular}

\section{Discussion}

The identifications carried out on the four samples resulted in the recognition of seven algal species, the systematic distribution of which is as follows: Cyanophyta, 2 species; Bacillariophyta, 1 varietas; Pyrrhophyta, 1 species; Chlorophyta, 2 species; and Rhodophyta, 1 species. The identified taxa and their localities in the cave is presented in Table 1.

It is immediately evident from this table that each of the four collections must represent an isolated microhabitat as only a single species occurred common to even two of the samples. This and the fact that samples Nos. 1 and 3 gave a unialgal culture and a culture showing only two species respectively, is probably the best proof of lack of cross contamination, or contamination by the air during the collecting and transferring processes. As the microscopic examination carried out immediately after our return affirmed the presence of chlorophyll containing, apparently actively assimilating algae in three of the four samples one may be reasonably sure of their indigenous nature in the cave.

Sample No. 2 deserves special mention. This collection contained macroscopically visible thalli of Asterocytis and in the mucus of this Bangioid red alga, 3 other algae occurred in considerable quantity, out of which Chamaesiphon gracilis is particularly noteworthy, which will be discussed later. Red algae have already been reported from caves, both from the photic and aphotic zones, representing atmophytic as well as true aquatic species. Thus Geitler (1943) reported Phragmonema sordidum Zopf from a small cave near Lunz, while Friedmann $(1957,1962)$ described the same species from two caves in 
Israel: Beit Guvrin 4, and Sanhedriya. All three of these occurrences however, were in the photic zone, i.e. there was enough light penetrating into the small caverns where this Rhodophyton thrived to supply it with the adequate amounts of energy necessary for its assimilatory activity.

Asterocytis, on the other hand, was found deep in the interior of the cave ( $450 \mathrm{~m}$. from the entrance) where it receives only some diffused, intermittent and short periods of illumination from a relatively distant electrical bulb. Even if one considers the relatively low light requirement of some algae the light available for Asterocytis in the cave clearly cannot be sufficient to supply it with adequate energy for assimilation. Thus the question of what energy source this Rhodophyton utilizes for its life function temporarily remains obscure.

Other Rhodophyta are known to occur in the total darkness of caves. Claus (1962a, 1962b) described a Chantransia chalybea - like form from the cave of Abaliget and another similar Chantransia species from Peace Cave, while quite recently Jones (1964) discovered Lemanea torulosa (Roth) Ag. in the Mammoth Cave. All three of these forms, however, belong to the Florideae and the occurrence of Asterocytis in a deep cave environment is the first report of a Bangioidea living under practically aphotic conditions. The discovery of this species in a true speleo-environment completes the list of representatives of all of the major classes of fresh water algae in caves.

A further interesting fact to bear in mind in connection with the occurrence of Asterocytis is that it was found growing on the wall of the cave, thus it appeared in an aerial environment. Of the other red algae reported from caves only Phragmonema is a true aerophyte while all of the others live under aquatic conditions, usually preferring rapidly flowing waters with high $\mathrm{O}_{2}$ content. The Chantransia $s p$. from Abaliget and Lemanea torulosa in Mammoth cave, however, also occurred either on the wall of the caves or were attached to old logs. This fact, i.e. aquatic plants occurring as aerophytes might well be due to the almost constant 100 per cent relative humidity of the cave environment.

The other noteworthy species occurring in Crystal Cave is Chamaesiphon gracilis. This form is known to be an epiphyte on other algae or higher aquatic plants, whereas in the cave it was found to grow on or in the thallus of Asterocytis. Later, in the cultures, it was attached to small mineral particles. The occurrence of a Dermocarpales in the speleo-environment is interesting enough by itself, but the fact that 
the Chamaesiphon grew on the thallus of an aerophyte under aerial conditions, furthermore that it was later possible to culture it in an artificial medium make its discovery even more important. It seems to be the first Chamaesiphonaceae ever reported from a cave and ever cultured successfully in a laboratory.

Due to the preliminary type of this work, and the randomness and scarcity of the samples collected, one cannot make any inferences as to the extent of the algal flora of Crystal Cave. One can, however, arrive at one tentative conclusion, i.e. the algae occurring in this cave are quite different to those found in any other investigated speleoenvironment. Except for Oscillatoria neglecta, which seems to be a quite common representative of many cave algal floras, not another species occurred in the samples which has been reported from the nearby Mammoth Cave (Jones, 1964). Thus if the cave algae would have originated or are still originating from the surface algal floras some common species to the two caves would have been expected. This not being the case, one may agree with the ideas of Claus (loc. citt.) that at least portions of the cave algal floras originate from the time of the cave's formation, thus representing a relict type of vegetation. This statement gains further confirmation by the occurrence of such interesting forms as the Asterocytis or Chamaesiphon discussed above.

\section{SUMMARY}

Collections of a preliminary type carried out in Crystal Cave, Kentucky, resulted in the identification of seven algal taxa. A Chamaesiphon (Dermocarpales) and an Asterocytis (Bangioidea) are reported for the first time from a speleo-environment. As no correlation could be found among the algae occurring in Crystal Cave and those of nearby Mammoth Cave the conclusion is reached that the cave algal floras do not originate from the algal vegetation of the surface but may have gotten into the caves at the time of the latter's formation.

\section{ZUSAMMENFASSUNG}

Sammlungen von vorläufigem Charakter wurden in der Crystal-Höhle (Kentucky) durchgeführt. Sie ergaben die Bestimmung von 7 Algentaxa. Eine Chamaesiphon (Dermocarpales) und eine Asterocytis (Bangioidea) wurden erstmalig aus einer Speleo-Umgebung beschrieben. Da keine Korrelation unter den aus der Crystal-Höhle und jenen aus der naheliegenden Mammoth-Höhle stammenden Algen festgestellt werden konnte, scheint die Folgerung bestätigt zu sein, daß die Algenfloren der Höhlen nicht von der außenweltlichen Algenvegetation abstammen, sondern daß sie in die Höhlen zur Zeit ihrer Entstehung eingebracht wurden. 


\section{REFERENCES}

Claus, G. (1955) - Algae and Their Mode of Life in the Baradla Cave at Aggtelek. Acta Bot. Acad. Sci. Hung. 2:1-26.

- (1960) - Re-evaluation of the Genus Gomontiella. Rev. Algol. Nouv. Ser. $5: 103-111$.

- (1962 a) - Beiträge zur Kenntnis der Algenflora der Abaligeter Höhle. Hydrobiologia 19:192-222.

- (1962 b) - Data on the Ecology of the Algae of Peace Cave in Hungary. Nova Hedwigia 4:55-79.

- (1964a) - Algae and Their Mode of Life in the Baradla Cave at Aggtelek. Part II. Internat. J. Speleol. 1(1-2):13-17.

- (1964b) - Daten zur Kenntnis der Algenflora der Höhle Kölyuk von Manfa. Internat. J. Speleol. 1(4):541-551.

Fried mann, I. (1955) - Geitleria calcarea n. gen. and n. sp. A New Atmophytic Lime-incrusting Blue-green Alga. Bot. Not. 108:439-445.

- (1956) - Beiträge zur Morphologie und Formwechsel der atmophytischen Bangioidee Phragmonena sordidum Zopf. Öster. Bot. Zeitschr. 103: 613-633.

- (1961) - Chroococcidiopsis kashaii sp.n. and the Genus Chroococcidiopsis. Öster. Bot. Zeitschr. 108:354-367.

- (1962) - The Ecology of the Atmophytic Nitrate-Alga Chroococcidiopsis kashaii Friedmann. Arch. Mikrobiol. 42:42-45.

Geitler, L. (1932) - Cyanophyceae: In Rabenhorst's Kryptogamenflora... 14:1-1196. Akad. Verlag, Leipzig.

- (1943) - Einige selten beobachtete Algen aus Lunz. Internat. Rev. ges. Hydrobiol. Hydrogr. 43:98-99.

Heering, W. (1914) - Chlorophyceae: In Pascher's Süßwasserflora... 6:1250. G. Fischer, Jena.

Jones, H. J. (1964) - Algological Investigations in Mammoth Cave, Kentucky. Internat. J. Speleol. 1(4):491-516.

Kylin, H. (1956) - Die Gattungen der Rhodophyceen. :1-673. Gleerups Förlag, Lund.

LeCouppey de La Forrest, M. (1903) - Quelques grottes des Etats-Unis d'Amérique. Spelunca 5 :(35) 21-34.

Maнeu, P. (1903) - La Flore Spéléologique. Riv. Ital. Spel. 1(4):11-15.

Palik, P. (1960a) - Study into the Algal Flora of Caves. Hidrol. Közl. $40: 417-422$.

- $(1960 \mathrm{~b})$ - A New Blue-green Alga from the Cave Baradla near Aggtelek. Ann. Univ. Sci. Budapestiensis R. Eötvös nom. 3:275-285.

Pascher, A., Schiller, J., and Migula, W. (1925) - Heterocontae, Phaeophyta, Rhodophyta, Charophyta: In Pascher's Süßwasserflora...11: 1-206. G. Fischer, Jena.

Schilter, J. (1933-1937) - Dinoflagellatae: In Rabenhorst's Kryptogamenflora... 10(2):1-589. Akad. Verlag, Leipzig.

Sмiтн, G. M. (1950) - The Fresh-water Algae of the United States.: 1-719. McGraw-Hill Co., New York, Toronto, London.

- (1964) - The Flint Ridge Cave System: 1957-1962. Bull. Nat. Speleol. Soc. 26:17-27. 
SubA, E. (1957) - Die Algen der Pálvölgyer Höhle in Ungarn. Verhandl. Zool-Bot. Ges. Wien. 97:97-109.

Watson, R. A., and Smith, P. M. (1963) - The Mammoth Cave National Park Research Center. 1-50. Cave Res. Found., Yellow Springs, Ohio.

Zabelina, M. M., Kiselev, I. A., Proshina-Lavrenko, A. I., and SheshuKovA, A. I. (1949) - Diatomovye vodorosli. in Opredelitelj presnovodnikh vodoroslej S.S.S.R. 4:1-619. Sovj. Nauk., Moskva. 